\title{
Skills Proficiency and Marketability of BS in Office Administration: Input Training Program
}

\author{
Ed Jesson G. Valiente, LPT, PhD \\ edjesson.valiente@1spu.edu.ph \\ Faculty Member, College of Buiness Mangement and Accountancy, Laguna State Polytechnic University, \\ Brgy. Bubukal, Sta. Cruz, Laguna, 4009, Philippines
}

\begin{abstract}
The researcher being so much interested in this issue, intend to investigate the BSOA vis-à-vis business offices. The result of this research project will go a long way in determining the importance of the skill to the BSOA students and its position, in relation to other courses. The participants of the study were composed of 46 BSOA graduating students and 18 industry workers.

The purpose of the study is to assess the level of skills proficiency among BSOAgraduating students in terms of stenography skills, computer/typing skills, record management skills; written communication skills/business correspondence; To test if there is a significant relationship between the level of skills proficiency of BSOA and its extent of marketability; Based on the results of the study, what training plan may be proposed to further enhance the skills proficiency of BSOA students?

The researcher used descriptive survey method in gathering and treating the data for this study. In the employment of this kind of research design, the researcher observed thoroughly the population frame of the study through careful definition and specific delimitation in order to set the precise parameter for answering the discreteness of its characteristics. Therefore, particular attention that will safeguard the data from the influence of bias by organizing and presenting them systematically so that valid and accurate conclusions had drawn as a basis for viable recommendations therein (Calmorin and Calmorin 2017). Purposive sampling technique was used. The questionnaire was employed to gather data. The frequency distribution, weighted mean, standard deviation. $t$ - test paired two sample for means was employed.
\end{abstract}

Keywords: stenography skills, business correspondence, maketability, record management skills, skills proficiency

\section{Introduction}

Today's business office is like a beehive with so much work, which consists principally of the administrative support and clerical activities associated with handling information. The information is needed for many decisions making and therefore, it needs to reach the 'right persons' in the 'correct form' at the 'appropriate time'. Here is where the role of the administrative support personnel comes into play. He/she is primary employed to assist the manager/executives in correspondence, literary work, getting information and other confidential matters. His/her duties are categorized into primary and secondary functions. The primary functions have to do with the basic administrative support personnel and clerical skills such as, typewriting, taking dictations, answering telephone, handling mail etc. 


\section{Literature Review}

Bachelor of Science in Office Administration (BSOA) is a four-year degree program designed to provide students with knowledge and skills in business management and office processes needed in different workplaces such as general offices, legal or medical offices. The BSOA program prepares students to be able to carry out clerical, administrative, supervisory and managerial tasks. In addition, the program also trains students to develop their skills in keyboarding, filing, shorthand and stenography.

Office Administration courses are commonly part of diploma, certificate and associate's degree programs, and occasionally bachelor's degree programs. Office administration studies programs are also called secretarial science, administrative assistants. Hands-on training during classes is usually provided, and cooperative deduction is part of some programs.

There are some schools who offer a ladderized curriculum for the BSOA program. For each year level a student completes, he/she receives a proficiency certificate. The proficiency certificate is granted to students who passed the competency test administered by the Technical Education and Skills Development Authority (TESDA). However, completion, of the four-year course entitles a student a full degree which will qualify him/her for higher positions.

\section{Methodology}

The researcher used descriptive survey method in gathering and treating the data for this study. In the employment of this kind of research design, the researcher observed thoroughly the population frame of the study through careful definition and specific delimitation in order to set the precise parameter for answering the discreteness of its characteristics. Therefore, particular attention that will safeguard the data from the influence of bias by organizing and presenting them systematically so that valid and accurate conclusions had drawn as a basis for viable recommendations therein (Calmorin and Calmorin 2017). Purposive sampling technique was used. The questionnaire was employed to gather data. The frequency distribution, weighted mean, standard deviation. $t$ - test paired two sample for means was employed. 


\section{Presentation, Analysis and Interpretation of Data}

Table 1. Assessment level of proficiency skills of BSOA graduating students with regards to Stenography skills

\begin{tabular}{llll}
\hline Statements & $\begin{array}{l}\text { Weighted } \\
\text { Mean }\end{array}$ & SD & Remarks \\
\hline $\begin{array}{l}\text { 1. Acquire mastery of shorthand theories of words and } \\
\text { vocabularies that are used in different documents. }\end{array}$ & 4.12 & 0.74 & Agree \\
$\quad$ 2. Possess adequate skills in spelling, punctuation, & 4.08 & 0.72 & Agree \\
grammar, and vocabulary usage as I transcribe in longhand. & & & \\
$\quad$ 3. Can take dictation at the rate of 50 words a minute. & 3.76 & 0.86 & $\begin{array}{l}\text { Agree } \\
\text { 4. Can transcribe a three-minute dictation with 100\% }\end{array}$ \\
$\begin{array}{l}\text { accuracy. } \\
\text { 5. Can read and write shorthand strokes accurately. }\end{array}$ & 3.80 & 0.83 & Agree \\
\hline
\end{tabular}

\begin{tabular}{|c|c|c|c|}
\hline \multicolumn{4}{|c|}{$\begin{array}{l}\text { Grand Mean }=3.95 \\
\text { Population Standard Deviation }=0.804 \\
\text { Verbal Interpretation = Evident }\end{array}$} \\
\hline \multicolumn{4}{|c|}{ Legend: } \\
\hline Scale & Range & Remarks & Verbal Interpretation \\
\hline 5 & $4.20-5.00$ & Strongly Agree & Highly Evident \\
\hline 4 & $3.40-4.19$ & Agree & Evident \\
\hline 3 & $2.60-3.39$ & Moderately Agree & Moderately Evident \\
\hline 2 & $1.80-2.59$ & Disagree & Less Evident \\
\hline 1 & $1.00-1.79$ & Strongly Disagree & Not Evident \\
\hline
\end{tabular}

Table 1 presents the assessment level of proficiency skills of BSOA graduating students with regards to Stenography skills, the first statement "Acquire mastery of shorthand theories of words and vocabularies that are used in different documents." got the highest ( $\mathrm{WM}=4.12, \mathrm{SD}=0.74)$ and with a remark of agree. Followed by the second statement "Possess adequate skills in spelling, punctuation, grammar, and vocabulary usage as I transcribe in longhand". with a $(\mathrm{WM}=4.08, \mathrm{SD}=0.72)$ and with a remark of agree. While the third statement "Can take dictation at the rate of 50 words a minute." received the lowest (WM = $3.76, \mathrm{SD}=0.86)$ and with a remark of agree.

With a $(\mathrm{GM}=3.95, \mathrm{SD}=0.804)$ the assessment level of proficiency skills of BSOA graduating students with regards to Stenography skills is evident. 
Table 2. Assessment level of proficiency skills of BSOA graduating students with regards to Computer/typing skills

\begin{tabular}{|c|c|c|c|c|c|}
\hline \multicolumn{3}{|c|}{ Statements } & $\begin{array}{l}\text { Weighted } \\
\text { Mean }\end{array}$ & SD & Remarks \\
\hline \multicolumn{3}{|c|}{$\begin{array}{l}\text { 1. Exhibit proficiency in the use of the computer and } \\
\text { other IT software. }\end{array}$} & 4.16 & 0.70 & Agree \\
\hline \multicolumn{3}{|c|}{$\begin{array}{l}\text { 2. Can encode a minimum speed of } 35 \text { words a minute } \\
\text { with one error per minute in a } 5 \text {-minute timed writing. }\end{array}$} & 3.95 & 0.75 & Agree \\
\hline \multicolumn{3}{|c|}{$\begin{array}{l}\text { 3. Exhibit proficiency in encoding business letters, } \\
\text { memoranda, tables and reports, manuscript, and financial } \\
\text { reports. }\end{array}$} & 3.96 & 0.69 & Agree \\
\hline \multirow{2}{*}{\multicolumn{3}{|c|}{$\begin{array}{l}\text { 4. Acquire dexterity in word processing, spreadsheet, } \\
\text { presentation, desktop publishing, and data management. }\end{array}$}} & 4.20 & 0.69 & $\begin{array}{l}\text { Strongly } \\
\text { Agree }\end{array}$ \\
\hline 5. $\mathrm{Mc}$ & & ch typing. & 4.00 & 0.80 & Agree \\
\hline $\begin{array}{l}\text { Gran } \\
\text { Popu } \\
\text { Verb }\end{array}$ & $\begin{array}{l}=4.05 \\
\text { tandard D } \\
\text { pretation }=\end{array}$ & $=0.730$ & & & \\
\hline \multicolumn{6}{|c|}{ Legend: } \\
\hline Scale & Range & Remarks & \multicolumn{3}{|l|}{ Verbal Interpretation } \\
\hline 5 & $4.20-5.00$ & Strongly Agree & \multicolumn{3}{|l|}{ Highly Evident } \\
\hline 4 & $3.40-4.19$ & Agree & \multicolumn{3}{|l|}{ Evident } \\
\hline 3 & $2.60-3.39$ & Moderately Agree & \multicolumn{3}{|l|}{ Moderately Evident } \\
\hline 2 & $1.80-2.59$ & Disagree & \multicolumn{3}{|l|}{ Less Evident } \\
\hline 1 & $1.00-1.79$ & Strongly Disagree & \multicolumn{3}{|l|}{ Not Evident } \\
\hline
\end{tabular}

Table 2 presents the assessment level of proficiency skills of BSOA graduating students with regards to Computer/typing skills, the fourth statement "Acquire dexterity in word processing, spreadsheet, presentation, desktop publishing, and data management." got the highest (WM = 4.20, SD =0.69) and with a remark of strongly agree. Followed by the first statement "Exhibit proficiency in the use of the computer and other IT software.". with a $(\mathrm{WM}=4.16, \mathrm{SD}=0.70)$ and with a remark of agree. While the second statement "Can encode a minimum speed of 35 words a minute with one error per minute in a 5-minute timed writing." received the lowest $(\mathrm{WM}=3.95, \mathrm{SD}=0.75)$ and with a remark of agree.

With a $(\mathrm{GM}=4.05, \mathrm{SD}=0.830)$ the assessment level of proficiency skills of BSOA graduating students with regards to Computer/typing skills is evident. 
Table 3. Assessment level of proficiency skills of BSOA graduating students with regards to Record management/filing skills

\begin{tabular}{|c|c|c|c|c|c|}
\hline \multicolumn{3}{|c|}{ Statements } & $\begin{array}{l}\text { Weighted } \\
\text { Mean }\end{array}$ & SD & Remarks \\
\hline \multicolumn{3}{|c|}{ 1. Can file accurately using manual filing system. } & 4.31 & 0.68 & $\begin{array}{l}\text { Strongly } \\
\text { Agree }\end{array}$ \\
\hline \multirow{2}{*}{\multicolumn{3}{|c|}{$\begin{array}{l}\text { 2. Can file accurately using electric filing system. } \\
\text { 3. Can organize files, information, and office supplies } \\
\text { effectively. }\end{array}$}} & 4.12 & 0.68 & Agree \\
\hline & & & 4.11 & 0.74 & Agree \\
\hline \multicolumn{3}{|c|}{$\begin{array}{l}\text { 4. Can monitor departmental materials, supplies, and } \\
\text { orders as needed. }\end{array}$} & 4.18 & 0.71 & Agree \\
\hline \multicolumn{3}{|c|}{$\begin{array}{l}\text { 5. Acquire mastery of record management rules and } \\
\text { procedures. }\end{array}$} & 4.25 & 0.80 & $\begin{array}{l}\text { Strongly } \\
\text { Agree }\end{array}$ \\
\hline \multicolumn{5}{|c|}{ Population Standard Deviation $=0.721$} & \\
\hline \multicolumn{6}{|l|}{ Legend: } \\
\hline Scale & Range & Remarks & \multicolumn{3}{|c|}{ Verbal Interpretation } \\
\hline 5 & $4.20-5.00$ & Strongly Agree & \multicolumn{3}{|c|}{ Highly Evident } \\
\hline 4 & $3.40-4.19$ & Agree & \multicolumn{3}{|l|}{ Evident } \\
\hline 3 & $2.60-3.39$ & Moderately Agree & \multicolumn{3}{|c|}{ Moderately Evident } \\
\hline 2 & $1.80-2.59$ & Disagree & \multicolumn{3}{|c|}{ Less Evident } \\
\hline 1 & $1.00-1.79$ & Strongly Disagree & \multicolumn{3}{|l|}{ Not Evident } \\
\hline
\end{tabular}

Table 3 presents the assessment level of proficiency skills of BSOA graduating students with regards to Record management/filing skills, the first statement "Can file accurately using manual filing system." got the highest $(\mathrm{WM}=4.31, \mathrm{SD}=0.68)$ and with a remark of strongly agree. Followed by the fifth statement "Acquire mastery of record management rules and procedures." with a (WM = 4.25, SD = 0.80) and with a remark of strongly agree. While the third statement "Can organize files, information, and office supplies effectively." received the lowest ( $\mathrm{WM}=4.11, \mathrm{SD}=0.74)$ and with a remark of agree.

With a $(\mathrm{GM}=4.20, \mathrm{SD}=0.721)$ the assessment level of proficiency skills of BSOA graduating students with regards to Record management/filing skills is highly evident. 
Table 4. Assessment level of proficiency skills of BSOA graduating students with regards to Written communication skills/ Business correspondence

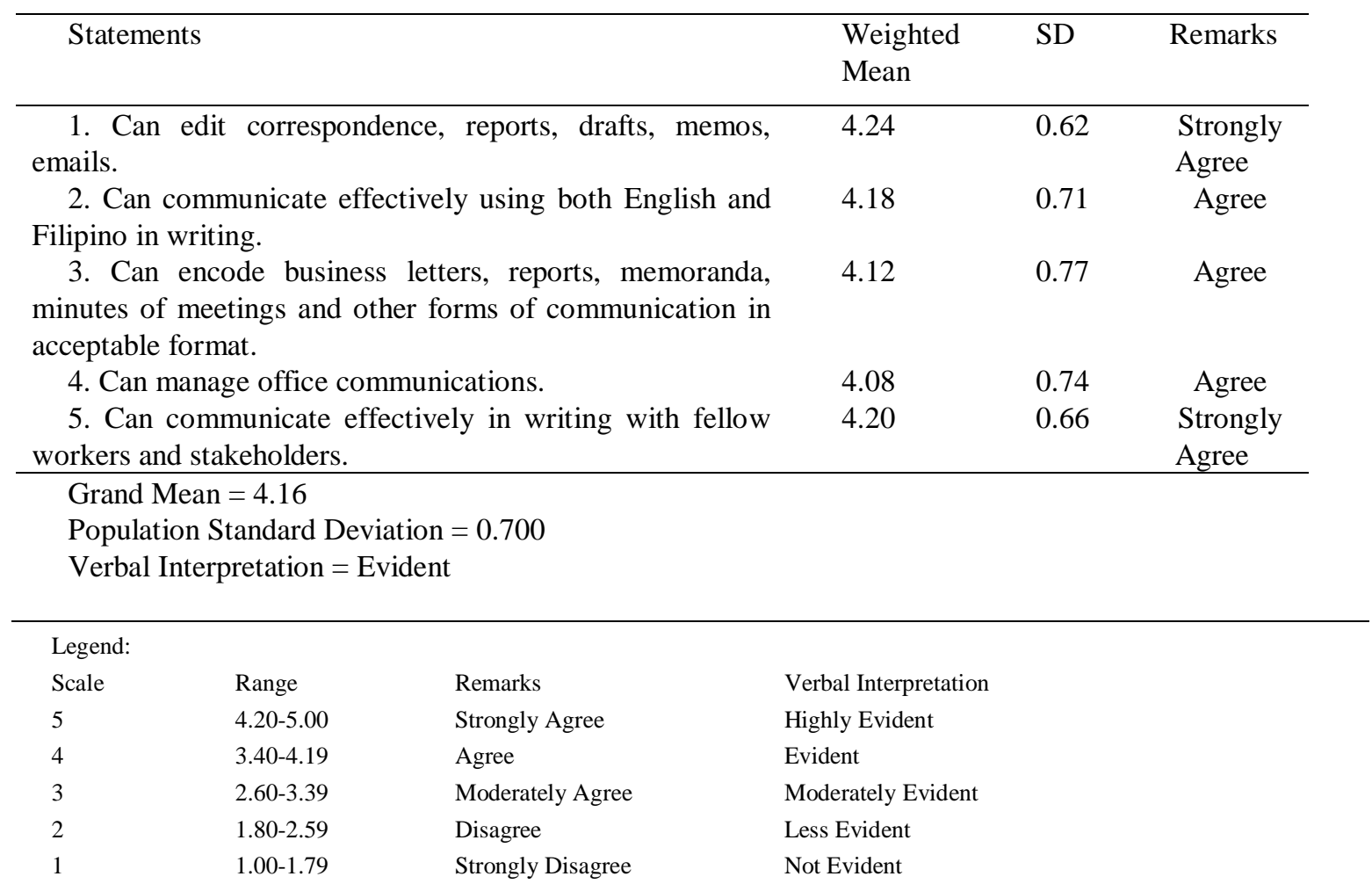

Table 4 presents the assessment level of proficiency skills of BSOA graduating students with regards to Written communication skills/ Business correspondence, the first statement "Can edit correspondence, reports, drafts, memos, emails." got the highest $(\mathrm{WM}=4.24, \mathrm{SD}=0.82)$ and with a remark of strongly agree. Followed by the fifth statement "Can communicate effectively in writing with fellow workers and stakeholders." with a (WM $=4.20, \mathrm{SD}=0.66)$ and with a remark of strongly agree. While the fourth statement "Can manage office communications." received the lowest ( $\mathrm{WM}=4.08, \mathrm{SD}=0.74)$ and with a remark of agree.

With a $(\mathrm{GM}=4.16, \mathrm{SD}=0.700)$ the assessment level of proficiency skills of BSOA graduating students with regards to Written communication skills/ Business correspondence is evident. 
Table 5. Composite Assessment level of proficiency skills of BSOA graduating students

\begin{tabular}{|c|c|c|c|c|c|c|}
\hline \multicolumn{4}{|c|}{ Indicators } & $\begin{array}{l}\text { Grand } \\
\text { Mean }\end{array}$ & $\mathrm{SD}$ & $\begin{array}{c}\text { Verbal } \\
\text { nterpretation }\end{array}$ \\
\hline \multicolumn{4}{|c|}{ Stenography skills } & 3.95 & 0.804 & Evident \\
\hline \multicolumn{4}{|c|}{ Computer/typing skills } & 4.05 & 0.730 & Evident \\
\hline \multicolumn{4}{|c|}{ Record management/filing skills } & 4.20 & 0.721 & Highly Evident \\
\hline \multicolumn{4}{|c|}{$\begin{array}{l}\text { Written communication skills/ } \\
\text { correspondence }\end{array}$} & 4.16 & 0.700 & Evident \\
\hline \multicolumn{7}{|c|}{$\begin{array}{l}\text { Total Mean }=4.09 \\
\text { Population Standard Deviation }=0.745 \\
\text { Verbal Interpretation = Evident }\end{array}$} \\
\hline \multicolumn{7}{|l|}{ Legend: } \\
\hline Scale & Range & \multicolumn{3}{|c|}{ Remarks } & \multicolumn{2}{|c|}{ Verbal Interpretation } \\
\hline 5 & $4.20-5.00$ & \multicolumn{3}{|c|}{ Strongly Agree } & \multicolumn{2}{|c|}{ Highly Evident } \\
\hline 4 & $3.40-4.19$ & \multicolumn{3}{|c|}{ Agree } & \multicolumn{2}{|c|}{ Evident } \\
\hline 3 & $2.60-3.39$ & \multicolumn{3}{|c|}{ Moderately Agree } & \multicolumn{2}{|c|}{ Moderately Evident } \\
\hline 2 & $1.80-2.59$ & \multicolumn{3}{|c|}{ Disagree } & \multicolumn{2}{|c|}{ Less Evident } \\
\hline 1 & $1.00-1.79$ & \multicolumn{3}{|c|}{ Strongly Disagree } & \multicolumn{2}{|c|}{ Not Evident } \\
\hline
\end{tabular}

Table 5 presents the composite assessment level of proficiency skills of BSOA graduating students, the indicator "Record management/filing skills" got the highest $(\mathrm{GM}=4.20, \mathrm{PSD}=0.721)$ and with a verbal interpretation of highly evident. Followed by the indicator "Written communication skills/ Business correspondence." with a $(\mathrm{GM}=4.16, \mathrm{PSD}=0.700)$ and with a verbal interpretation of evident. While the indicator "Stenography skills." receive the lowest $(\mathrm{GM}=3.95, \mathrm{PSD}=0.804)$ and with a verbal interpretation of evident.

With a $(\mathrm{TM}=4.09$, PSD $=0.745)$ the composite assessment level of proficiency skills of BSOA graduating students is evident. 
Table 6. Marketability level of proficiency skills of BSOA students as perceived by the industry with regards to Shorthand/Stenography skills

\begin{tabular}{|c|c|c|c|}
\hline Statements & $\begin{array}{l}\text { Weighted } \\
\text { Mean }\end{array}$ & SD & Remarks \\
\hline $\begin{array}{l}\text { 1. Prefer applicants who acquire mastery of shorthand } \\
\text { theories of words and vocabularies that are used in different } \\
\text { documents. }\end{array}$ & 4.43 & 0.86 & $\begin{array}{l}\text { Strongly } \\
\text { Agree }\end{array}$ \\
\hline $\begin{array}{l}\text { 2. Prefer applicants who possess adequate skills in } \\
\text { spelling, punctuation, grammar, and vocabulary usage. }\end{array}$ & 4.78 & 0.43 & $\begin{array}{l}\text { Strongly } \\
\text { Agree }\end{array}$ \\
\hline $\begin{array}{l}\text { 3. Prefer applicants who can take dictation at the rate of } 50 \\
\text { words a minute. }\end{array}$ & 4.67 & 0.49 & $\begin{array}{l}\text { Strongly } \\
\text { Agree }\end{array}$ \\
\hline $\begin{array}{l}\text { 4. Prefer applicants who can transcribe a three-minute } \\
\text { dictation with } 100 \% \text { accuracy. }\end{array}$ & 4.44 & 0.70 & $\begin{array}{l}\text { Strongly } \\
\text { Agree }\end{array}$ \\
\hline $\begin{array}{l}\text { 5. Prefer applicants who can read and write shorthand } \\
\text { strokes accurately. }\end{array}$ & 4.72 & 0.57 & $\begin{array}{l}\text { Strongly } \\
\text { Agree }\end{array}$ \\
\hline
\end{tabular}

Grand Mean $=4.61$

Population Standard Deviation $=0.961$

Verbal Interpretation $=$ Highly Evident

\begin{tabular}{llll}
$\begin{array}{l}\text { Legend: } \\
\text { Scale }\end{array}$ & Range & \multicolumn{1}{c}{ Remarks } & Verbal Interpretation \\
5 & $4.20-5.00$ & Strongly Agree & Highly Evident \\
4 & $3.40-4.19$ & Agree & Evident \\
3 & $2.60-3.39$ & Moderately Agree & Moderately Evident \\
2 & $1.80-2.59$ & Disagree & Less Evident \\
1 & $1.00-1.79$ & Strongly Disagree & Not Evident
\end{tabular}

Table 6 presents the Marketability level of proficiency skills of BSOA students as perceived by the industry with regards to Shorthand/Stenography skills, the second statement "Prefer applicants who possess adequate skills in spelling, punctuation, grammar, and vocabulary usage." got the highest $(\mathrm{WM}=4.78, \mathrm{SD}=$ 0.43 ) and with a remark of strongly agree. Followed by the fifth statement "Prefer applicants who can read and write shorthand strokes accurately." with a $(\mathrm{WM}=4.72, \mathrm{SD}=0.57)$ and with a remark of strongly agree. While the first statement "Prefer applicants, who acquire mastery of shorthand theories of words and vocabularies that are used in different documents." received the lowest $(\mathrm{WM}=4.43, \mathrm{SD}=0.86)$ and with a remark of strongly agree.

With a $(\mathrm{GM}=4.61, \mathrm{SD}=0.961)$ the Marketability level of proficiency skills of BSOA students as perceived by the industry with regards to Shorthand/Stenography skills is highly evident. 
Table 7. Marketability level of proficiency skills of BSOA students as perceived by the industry with regards to Computer/Keyboarding skills

\begin{tabular}{|c|c|c|c|}
\hline Statements & $\begin{array}{l}\text { Weighted } \\
\text { Mean }\end{array}$ & SD & Remarks \\
\hline $\begin{array}{l}\text { 1. Prefer applicants who exhibit proficiency in the use of } \\
\text { the computer and other IT software. }\end{array}$ & 4.50 & 0.51 & $\begin{array}{l}\text { Strongly } \\
\text { Agree }\end{array}$ \\
\hline $\begin{array}{l}\text { 2. Prefer applicants who can encode a minimum speed of } \\
35 \text { words a minute with one error per minute in a } 5 \text {-minute } \\
\text { timed writing. }\end{array}$ & 4.39 & 0.50 & $\begin{array}{l}\text { Strongly } \\
\text { Agree }\end{array}$ \\
\hline $\begin{array}{l}\text { 3. Prefer applicants who exhibit proficiency in encoding } \\
\text { business letters, memoranda, tables and reports, manuscript, } \\
\text { and financial reports. }\end{array}$ & 4.61 & 0.50 & $\begin{array}{l}\text { Strongly } \\
\text { Agree }\end{array}$ \\
\hline $\begin{array}{l}\text { 4. Prefer applicants who acquire dexterity in word } \\
\text { processing, spreadsheet, presentation, desktop publishing, } \\
\text { and data management. }\end{array}$ & 4.33 & 0.49 & $\begin{array}{l}\text { Strongly } \\
\text { Agree }\end{array}$ \\
\hline $\begin{array}{l}\text { 5. Prefer applicants who master the keyboard by touch } \\
\text { typing. }\end{array}$ & 4.44 & 0.51 & $\begin{array}{l}\text { Strongly } \\
\text { Agree }\end{array}$ \\
\hline
\end{tabular}

Grand Mean $=4.45$

Population Standard Deviation $=0.836$

Verbal Interpretation $=$ Highly Evident

$\begin{array}{llll}\text { Legend: } & & & \\ \text { Scale } & \text { Range } & \text { Remarks } & \text { Verbal Interpretation } \\ 5 & 4.20-5.00 & \text { Strongly Agree } & \text { Highly Evident } \\ 4 & 3.40-4.19 & \text { Agree } & \text { Evident } \\ 3 & 2.60-3.39 & \text { Moderately Agree } & \text { Moderately Evident } \\ 2 & 1.80-2.59 & \text { Disagree } & \text { Less Evident } \\ 1 & 1.00-1.79 & \text { Strongly Disagree } & \text { Not Evident }\end{array}$

Table 7 presents the Marketability level of proficiency skills of BSOA students as perceived by the industry with regards to Computer/Keyboarding skills, the third statement "Prefer applicants who exhibit proficiency in encoding business letters, memoranda, tables and reports, manuscript, and financial reports." got the highest $(\mathrm{WM}=4.61, \mathrm{SD}=0.50)$ and with a remark of strongly agree. Followed by the first statement "Prefer applicants who exhibit proficiency in the use of the computer and other IT software." with a (WM = $4.50, \mathrm{SD}=0.51)$ and with a remark of strongly agree. While the fourth statement "Prefer applicants, who acquire dexterity in word processing, spreadsheet, presentation, desktop publishing, and data management." received the lowest $(\mathrm{WM}=4.33, \mathrm{SD}=0.49)$ and with a remark of strongly agree.

With a $(\mathrm{GM}=4.46, \mathrm{SD}=0.836)$ the Marketability level of proficiency skills of BSOA students as perceived by the industry with regards to Computer/Keyboarding skills is highly evident. 
Table 8. Marketability level of proficiency skills of BSOA as perceived by the industry students with regards to Record management/filing skills

\begin{tabular}{|c|c|c|c|c|c|}
\hline \multicolumn{3}{|c|}{ Statements } & $\begin{array}{l}\text { Weighted } \\
\text { Mean }\end{array}$ & SD & Remarks \\
\hline \multicolumn{3}{|c|}{$\begin{array}{l}\text { 1. Prefer applicants who can file accurately using manual } \\
\text { filing system. }\end{array}$} & 4.61 & 0.50 & $\begin{array}{l}\text { Strongly } \\
\text { Agree }\end{array}$ \\
\hline \multicolumn{3}{|c|}{$\begin{array}{l}\text { 2. Prefer applicants can file accurately using electric } \\
\text { filing system. }\end{array}$} & 4.17 & 0.62 & Agree \\
\hline \multicolumn{3}{|c|}{$\begin{array}{l}\text { 3. Prefer applicants who can organize files, information, } \\
\text { and office supplies effectively. }\end{array}$} & 4.62 & 0.50 & $\begin{array}{l}\text { Strongly } \\
\text { Agree }\end{array}$ \\
\hline \multicolumn{3}{|c|}{$\begin{array}{l}\text { 4. Prefer applicants who can monitor departmental } \\
\text { materials, supplies, and orders as needed. }\end{array}$} & 4.33 & 0.69 & $\begin{array}{l}\text { Strongly } \\
\text { Agree }\end{array}$ \\
\hline \multicolumn{3}{|c|}{$\begin{array}{l}\text { 5. Prefer applicants who acquire mastery of record } \\
\text { management rules and procedures. }\end{array}$} & 4.56 & 0.51 & $\begin{array}{l}\text { Strongly } \\
\text { Agree }\end{array}$ \\
\hline \multicolumn{6}{|c|}{$\begin{array}{l}\text { Grand Mean }=4.46 \\
\text { Population Standard Deviation }=0.816 \\
\text { Verbal Interpretation = Highly Evident }\end{array}$} \\
\hline \multicolumn{6}{|l|}{ Legend: } \\
\hline Scale & Range & Remarks & \multicolumn{3}{|l|}{ Verbal Interpretation } \\
\hline 5 & $4.20-5.00$ & Strongly Agree & \multicolumn{3}{|l|}{ Highly Evident } \\
\hline 4 & $3.40-4.19$ & Agree & \multicolumn{3}{|l|}{ Evident } \\
\hline 3 & $2.60-3.39$ & Moderately Agree & \multicolumn{3}{|l|}{ Moderately Evident } \\
\hline 2 & $1.80-2.59$ & Disagree & \multicolumn{3}{|l|}{ Less Evident } \\
\hline 1 & $1.00-1.79$ & Strongly Disagree & \multicolumn{3}{|l|}{ Not Evident } \\
\hline
\end{tabular}

Table 8 presents the Marketability level of proficiency skills of BSOA students as perceived by the industry with regards to Record management/filing skills, the third statement "Prefer applicants who can organize files, information, and office supplies effectively." got the highest (WM = 4.62, SD =0.50) and with a remark of strongly agree. Followed by the first statement "Prefer applicants who can file accurately using manual filing system." with a $(\mathrm{WM}=4.61, \mathrm{SD}=0.50)$ and with a remark of strongly agree. While the second statement "Prefer applicants can file accurately using electric filing system." received the lowest (WM = $4.17, \mathrm{SD}=0.62$ ) and with a remark of agree.

With a $(\mathrm{GM}=4.46, \mathrm{SD}=0.816)$ the Marketability level of proficiency skills of BSOA students as perceived by the industry with regards to Record management/filing skills is highly evident. 
Table 9. Marketability level of proficiency skills of BSOA students as perceived by the industry with regards to Written communication skills/ Business correspondence

\begin{tabular}{|c|c|c|c|}
\hline Statements & $\begin{array}{l}\text { Weighted } \\
\text { Mean }\end{array}$ & SD & Remarks \\
\hline $\begin{array}{l}\text { 1. Prefer applicants who can edit correspondence, } \\
\text { reports, drafts, memos, emails. }\end{array}$ & 4.50 & 0.51 & $\begin{array}{l}\text { Strongly } \\
\text { Agree }\end{array}$ \\
\hline $\begin{array}{l}\text { 2. Prefer applicants who can communicate effectively } \\
\text { using both English and Filipino in writing. }\end{array}$ & 4.67 & 0.49 & $\begin{array}{l}\text { Strongly } \\
\text { Agree }\end{array}$ \\
\hline $\begin{array}{l}\text { 3. Prefer applicants who can encode business letters, } \\
\text { reports, memoranda, minutes of meetings and other forms } \\
\text { of communication in acceptable format. }\end{array}$ & 4.49 & 0.51 & $\begin{array}{l}\text { Strongly } \\
\text { Agree }\end{array}$ \\
\hline 4. Prefer applicants manage office communications. & 4.50 & 0.51 & $\begin{array}{l}\text { Strongly } \\
\text { Agree }\end{array}$ \\
\hline $\begin{array}{l}\text { 5. Prefer applicants who can communicate effectively in } \\
\text { writing with fellow workers and stakeholders. }\end{array}$ & 4.61 & 0.50 & $\begin{array}{l}\text { Strongly } \\
\text { Agree }\end{array}$ \\
\hline
\end{tabular}

$\begin{array}{llll}\begin{array}{l}\text { Legend: } \\ \text { Scale }\end{array} & \text { Range } & \text { Remarks } & \\ 5 & 4.20-5.00 & \text { Strongly Agree } & \text { Verbal Interpretation } \\ 4 & 3.40-4.19 & \text { Agree } & \text { Highly Evident } \\ 3 & 2.60-3.39 & \text { Moderately Agree } & \text { Evident } \\ 2 & 1.80-2.59 & \text { Disagree } & \text { Moderately Evident } \\ 1 & 1.00-1.79 & \text { Strongly Disagree } & \text { Not Evident }\end{array}$

Table 9 presents the Marketability level of proficiency skills of BSOA students as perceived by the industry with regards to Written communication skills/ Business correspondence, the second statement "Prefer applicants who can communicate effectively using both English and Filipino in writing." got the highest (WM $=4.67, \mathrm{SD}=0.49$ ) and with a remark of strongly agree. Followed by the fifth statement "Prefer applicants who can communicate effectively in writing with fellow workers and stakeholders." with a (WM = $4.61, \mathrm{SD}=0.50$ ) and with a remark of strongly agree. While the third statement "Prefer applicants, who can encode business letters, reports, memoranda, minutes of meetings and other forms of communication in acceptable format." received the lowest $(\mathrm{WM}=4.17, \mathrm{SD}=0.62)$ and with a remark of agree.

With a $(\mathrm{GM}=4.56, \mathrm{SD}=0.828)$ the Marketability level of proficiency skills of BSOA students as perceived by the industry with regards to Written communication skills/ Business correspondence is highly evident. 
Table 10. Composite Marketability level of proficiency skills of BSOA students as perceived by the industry

\begin{tabular}{llll}
\hline Indicators & $\begin{array}{l}\text { Grand } \\
\text { Mean }\end{array}$ & SD & $\begin{array}{c}\text { Verbal } \\
\text { Interpretation }\end{array}$ \\
\hline Shorthand/Stenography skills & 4.61 & 0.961 & Highly Evident \\
Computer/Keyboarding skills & 4.45 & 0.836 & Highly Evident \\
Record management/filing skills & 4.46 & 0.816 & Highly Evident \\
$\begin{array}{l}\text { Written communication skills/ Business } \\
\text { correspondence }\end{array}$ & 4.56 & 0.828 & Highly Evident \\
\hline
\end{tabular}

Total Mean $=4.52$

Population Standard Deviation $=0.558$

Verbal Interpretation = Evident

$\begin{array}{llll}\text { Legend: } & & \\ \text { Scale } & \text { Range } & \text { Remarks } & \text { Verbal Interpretation } \\ 5 & 4.20-5.00 & \text { Strongly Agree } & \text { Highly Evident } \\ 4 & 3.40-4.19 & \text { Agree } & \text { Evident } \\ 3 & 2.60-3.39 & \text { Moderately Agree } & \text { Moderately Evident } \\ 2 & 1.80-2.59 & \text { Disagree } & \text { Less Evident } \\ 1 & 1.00-1.79 & \text { Strongly Disagree } & \text { Not Evident }\end{array}$

Table 10 presents the composite marketability level of proficiency skills of BSOA students as perceived by the industry, the indicator "Shorthand/Stenography skills" got the highest $(\mathrm{GM}=4.61, \mathrm{PSD}=$ 0.961 ) and with a verbal interpretation of highly evident. Followed by the indicator "Written communication skills/ Business correspondence." with a $(\mathrm{GM}=4.56$, PSD $=0.828)$ and with a verbal interpretation of evident. While the indicator "Computer/Keyboarding skills." receive the lowest (GM $=4.45, \mathrm{PSD}=0.836)$ and with a verbal interpretation of highly evident.

With a $(\mathrm{TM}=4.52$, PSD $=0.558)$ the composite marketability level of proficiency skills of BSOA students as perceived by the industry is highly evident. 
Table 11. Significant relationship between proficiency skills and Marketability level of BSOA students as perceived by the industry

\begin{tabular}{|c|c|c|c|c|c|}
\hline $\begin{array}{l}\text { Skills } \\
\text { Proficiency }\end{array}$ & $\begin{array}{l}\text { Marketability level of } \\
\text { BSOA students as } \\
\text { perceived by the industry }\end{array}$ & r-computed & $p$-value & $\begin{array}{l}\text { Degree of } \\
\text { Correlation }\end{array}$ & Analysis \\
\hline & Stenography skills & 0.4414 & 0.0000 & $\begin{array}{l}\text { Moderate } \\
\text { correlation }\end{array}$ & Significant \\
\hline & Computer/typing skills & 0.3361 & 0.0000 & $\begin{array}{l}\text { Slight } \\
\text { correlation }\end{array}$ & Significant \\
\hline & $\begin{array}{l}\text { Record management/filing } \\
\text { skills }\end{array}$ & 0.3592 & 0.0008 & $\begin{array}{l}\text { Slight } \\
\text { correlation }\end{array}$ & Significant \\
\hline & $\begin{array}{l}\text { Written communication } \\
\text { skills/ Business } \\
\text { correspondence }\end{array}$ & 0.3504 & 0.0002 & $\begin{array}{l}\text { Slight } \\
\text { correlation }\end{array}$ & Significant \\
\hline
\end{tabular}

\begin{tabular}{ll}
\hline Legend & \\
Scale & Interpretation \\
\pm 0.00 & no correlation, no relationship \\
$\pm 0.01- \pm 0.20$ & very low correlation, almost negligible relationship \\
$\pm 0.21- \pm 0.40$ & slight correlation, definite but small relationship \\
$\pm 0.41- \pm 0.70$ & moderate correlation, substantial relationship \\
$\pm 0.71- \pm 0.90$ & high correlation, marked relationship \\
$\pm 0.91- \pm 0.99$ & very high correlation, very dependable relationship \\
\pm 1.00 & perfect correlation, perfect relationship
\end{tabular}

Table 11 presents the significant relationship between the proficiency skills and Marketability level of BSOA students as perceived by the industry

In determining the relationship between the proficiency skills and Marketability level of BSOA students as perceived by the industry the data were statistically treated between the two variables that which arrived to the computed value $r$-value for the indicators of the proficiency skills and Marketability level of BSOA students as perceived by the industry. It shows that all indicators have a degree of correlation of Slight to Moderate.

Based on the data, it is shown that there is a "significant relationship between the proficiency skills and Marketability level of BSOA students as perceived by the industry." at 0.05 level of significance. It shows that the null hypothesis stating that "There is no significant relationship between the proficiency skills and Marketability level of BSOA students as perceived by the industry." is rejected thus the alternative hypothesis is accepted, it can infer that there is a "significant" relationship between them. 


\section{Conclusion}

On the basis of the foregoing findings and hypotheses posted in this research the conclusion was drawn.

1. The composite assessment level of proficiency skills of BSOA graduating students, the indicator "Record management/filing skills" got the highest $(\mathrm{GM}=4.20, \mathrm{PSD}=0.721)$ and with a verbal interpretation of highly evident. Followed by the indicator "Written communication skills/ Business correspondence." with a $(\mathrm{GM}=4.16$, PSD $=0.700)$ and with a verbal interpretation of evident. While the indicator "Stenography skills." receive the lowest $(\mathrm{GM}=3.95, \mathrm{PSD}=0.804)$ and with a verbal interpretation of evident. With a $(\mathrm{TM}=4.09, \mathrm{PSD}=0.745)$ the composite assessment level of proficiency skills of BSOA graduating students is evident.

2. The composite marketability level of proficiency skills of BSOA students as perceived by the industry, the indicator "Shorthand/Stenography skills" got the highest $(\mathrm{GM}=4.61, \mathrm{PSD}=0.961)$ and with a verbal interpretation of highly evident. Followed by the indicator "Written communication skills/ Business correspondence." with a $(\mathrm{GM}=4.56, \mathrm{PSD}=0.828)$ and with a verbal interpretation of evident. While the indicator "Computer/Keyboarding skills." receive the lowest (GM $=4.45$, PSD $=0.836)$ and with a verbal interpretation of highly evident. With a $(\mathrm{TM}=4.52, \mathrm{PSD}=0.558)$ the composite marketability level of proficiency skills of BSOA students as perceived by the industry is highly evident.

3. The indicators of the proficiency skills and Marketability level of BSOA students as perceived by the industry. It shows that all indicators have a degree of correlation of Slight to Moderate.

4. It is shown that there is a "significant relationship between the proficiency skills and Marketability level of BSOA students as perceived by the industry." at 0.05 level of significance. It shows that the null hypothesis stating that "There is no significant relationship between the proficiency skills and Marketability level of BSOA students as perceived by the industry." is rejected thus the alternative hypothesis is accepted, it can infer that there is a "significant" relationship between them.

\section{Recommendation}

1. Enhance the shorthand/stenography skills of BSOA students through a competency-based shorthand instruction.

2. Update the knowledge and skills through seminars and training.

3. Develop a training plan based on the results of the study to further enhance the skills proficiency of BSOA students is highly recommended. 


\section{Literature Cited}

SKIMIN (1973) Competency-Based Shorthand Instruction, The Journal of Business Education, 49:3, 103-104, DOI:

CALMORINA A., CALMORIN E. (2017) Methods of Research: Research Methods and Thesis Writing, Rex Bookstore, Inc.

AVENI, T. (2019). Passive Haptic Learning for Computer Stenography. Retrieve from: https://smartech.gatech.edu

EGER, DON (2011). Theory of Performance. Retrieve from: https://www.webpages.uidaho.edu

KRISTENSSON, P. \& SHUMIN, Z., (2015). Shorthand writing on stylus keyboard. Proceedings of the SIGCHI Conference on Human Factors in Computing Systems. Retrieve from: https://dl.acm.org

KUMAR, P., NARENDRA, T. V., \& VINAY N. A. (2017). International Journal of Advanced Research in Computer Science and Software Engineering. Short Hand Recognition using Canny Edge Detector. Retrieve from: https://www.researchgate.net

LANG, T. (2019). The long and the short of abbreviations. Tom Lang Communications and Training International. Retrieve from: https://europeanscienceediting.eu

MONTALBO, FJ. P., \& BARFEH, DP. (2019). Classification of Stenography using Convolutional Neural Networks and Canny Edge Detection Algorithm. Retrieve from: https://ieeexplore.ieee.org

RUBIN, K., WESTVANG, E., ROSTAD, O., \& (2018). Method of creating a chording keyboard mapping table. Retrieve from: https://patents.patsnap.com 